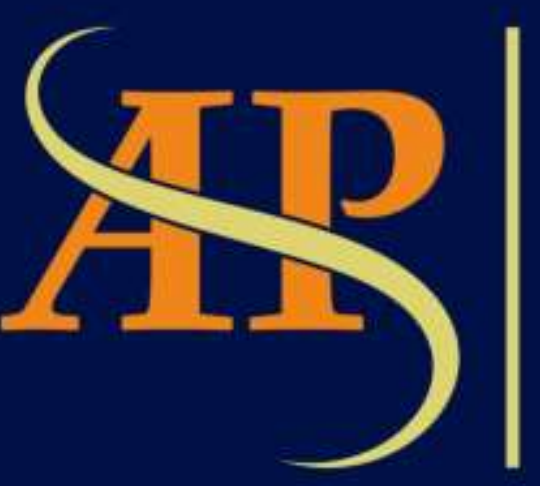

JURNAL

ASIA

PACIFIC

STUDIES

Journal of International Relations Study Program Faculty of Social and Political Sciences

Universitas Kristen Indonesia

Volume 4 | Number 2 | July - December 2020 


\title{
ANALISIS KERJASAMA SECRETARIAT OF THE PACIFIC REGIONAL ENVIRONMENT PROGRAMME (SPREP) TERKAIT PERUBAHAN IKLIM
}

\author{
${ }^{1}$ Regina Princesa, ${ }^{2}$ Rudi Kogoya, ${ }^{3}$ Renalda Ester, ${ }^{4}$ Retta Marito, ${ }^{5}$ Renaldi Christian \\ Program Studi Hubungan Internasional, FISIPOL, Universitas Kristen Indonesia \\ Jl. Mayjen Sutoyo No.2, Cawang, Kec. Kramat jati, Kota Jakarta Timur, Daerah Khusus Ibukota Jakarta 13630 \\ ${ }^{1}$ regina.princesa74@gmail.com, ${ }^{2}$ rudikogoya2000@gmail.com, ${ }^{3}$ renaldaesterangkouw@gmail.com, \\ ${ }^{4}$ tambunanretta@gmail.com, ${ }^{5}$ renaldichss@gmail.com
}

\begin{abstract}
Climate Action or handling related to climate change is one of the important points of the 17 goals contained in the Sustainable Development Goals (SDGs). Climate change has recently become a serious problem in the international world, so it really needs deep attention from every country or region. As is the case in the Pacific Islands region, climate change is a threat that can disrupt sustainable development in this region, especially since there is an issue of rising sea levels which can drown the islands in it. With this climate change problem, one way that can be done is to take action or take action. Based on this background, an intergovernmental body called The Secretariat of the Pacific Regional Environment (SPREP) was formed to deal with problems regarding climate change in the Pacific Islands. The aim of SPREP itself is to promote cooperation in the Pacific region, provide assistance to protect and enhance the environment, and to ensure sustainable development for present and future generations. The framework used in this article is based on the theory of liberalism.
\end{abstract}

Keywords: Pacific Island, SPREP, climate change

\begin{abstract}
Abstrak
Climate Action atau penanganan terkait perubahan iklim merupakan salah satu poin penting dari 17 tujuan yang terdapat dalam Sustainable Development Goals (SDGs). Perubahan iklim akhir-akhir ini merupakan masalah yang cukup serius dalam dunia internasional, sehingga sangat dibutuhkan perhatian yang mendalam dari setiap negara ataupun kawasan. Seperti halnya yang terjadi di wilayah Kepulauan Pasifik, perubahan iklim merupakan suatu ancaman yang dapat mengganggu pembangunan berkelanjutan di wilayah ini, terlebih lagi adanya isu kenaikan air laut yang dapat menenggelamkan pulau-pulau didalamnya. Dengan adanya permasalahan perubahan iklim ini, salah satu cara yang dapat dilakukan yaitu melakukan pergerakan atau tindakan. Berdasarkan latar belakang tersebut, dibentuklah badan antar pemerintah yang dinamakan The Secretariat of the Pacific Regional Environment (SPREP) untuk menangani permasalahan mengenai perubahan iklim di Kepulauan Pasifik. Tujuan dari SPREP itu sendiri adalah untuk mempromosikan kerjasama di kawasan Pasifik, memberikan bantuan untuk melindungi dan meningkatkan lingkungan, serta untuk memastikan pembangunan berkelanjutan bagi generasi sekarang dan masa depan. Kerangka pemikiran yang digunakan dalam artikel ini didasarkan pada teori liberalisme.
\end{abstract}

Kata kunci: Kepulauan Pasifik, SPREP, perubahan iklim 


\section{Pendahuluan}

The Secretariat of the Pacific Regional Environment Program (SPREP) adalah badan antar pemerintah yang memberikan bantuan dan layanan konsultasi teknis kepada negaranegara Kepulauan Pasifik, dalam konservasi dan pengelolaan lingkungan, mereka ada untuk memastikan bahwa generasi sekarang dan masa depan mencapai pertumbuhan yang berkelanjutan. Keanggotaan SPREP mencakup 21 negara Pasifik dan 5 negara maju (Australia, Selandia Baru, Prancis, Kerajaan Inggris Raya dan Irlandia Utara, dan Amerika Serikat). SPREP memiliki lebih dari 90 pekerja yang ada, dengan setidaknya 20 pekerja berkomitmen untuk bekerja penuh waktu terkait isu-isu iklim. SPREP itu sendiri merupakan pusat keunggulan geografis dan badan terkemuka untuk Pasifik di bidang perubahan iklim. Sekitar 100 program regional mengenai bantuan donor telah dimulai di bidang perubahan iklim dan kelestarian lingkungan, yang secara umum, membantu pembuat kebijakan dalam ranah Climate Change Adaptation (CCA) dan Disaster Risk Reduction (DRR). SPREP awalnya dibentuk sebagai bagian dari Komisi Pasifik Selatan oleh pemerintah dan administrasi negara-negara kawasan Pasifik pada tahun 1973 (Secretariat of the Pacific Community (SPC)). Karena ada kebutuhan untuk menyelesaikan sejumlah masalah lingkungan di kawasan Pasifik, SPC berkembang dengan cepat dan menjadi badan otonom pada tahun 1982.

Di kawasan Pasifik, SPREP telah menjadi badan antar pemerintah utama dengan misi membina kerja sama lingkungan, menawarkan pelestarian lingkungan dan peningkatan bantuan serta memastikan keberlanjutan untuk generasi sekarang dan mendatang. Hal ini memupuk niat kerjasama untuk memastikan pembangunan berkelanjutan antar negara di kawasan Pasifik. Visi SPREP itu sendiri adalah memperkuat kapasitas warga Kepulauan Pasifik dalam mempersiapkan, melindungi, mengendalikan, dan menggunakan lingkungannya untuk pertumbuhan yang berkelanjutan. Perubahan iklim telah menjadi prioritas tertinggi di tingkat kawasan, di antara 14 masalah lingkungan yang terdapat di kawasan Pasifik. SPREP telah diminta untuk membantu masalah pengungsian dan kerusakan oleh anggota Negara Kepulauan Pasifik sejak 2006. Para pemimpin Kepulauan Pasifik telah berulang kali meminta SPREP untuk memimpin koordinasi masalah perubahan iklim di seluruh Kepulauan Pasifik dan memberikan mandat yang kuat untuk menawarkan bantuan kepada Layanan Meteorologi Nasional yang mengumpulkan data iklim dan menyediakan layanan-layanan terkaitnya.

Salah satu program perubahan iklim sebelumnya yang dimulai pada tahun 1997 sampai 2001 dengan biaya \$ 4,5 juta adalah Pacific Islands Climate Change Assistance Program (PICCAP). Proyek ini disponsori oleh Global Environment Facility (GEF) dan dilaksanakan oleh SPREP untuk membantu sepuluh negara Kepulauan Pasifik yang telah menandatangani dan meratifikasi United Nations Framework Convention on Climate Change (UNFCCC) dengan memantau, mempersiapkan dan meningkatkan kapasitas negara Pasifik dalam menghadapi isu perubahan iklim. Tujuan utama dari program ini adalah untuk memungkinkan Korespondensi Nasional Awal untuk disimpulkan oleh UNFCCC. Selain itu, inisiatif ini juga dapat diterapkan pada tugas-tugas lain, karena pembiayaannya cukup luas untuk memungkinkan persiapan risiko dan adaptasi dan beberapa survei lokasi individu untuk memungkinkan persiapan kegiatan adaptasi.

Salah satu dari empat program implementasi strategis SPREP 2011-2015 adalah program mengenai perubahan iklim. Tujuan prioritas strategis perubahan iklim adalah untuk meningkatkan kapasitas seluruh anggota dalam merespon perubahan iklim pada tahun 2015 melalui perubahan kebijakan, pengenalan strategi adaptasi yang realistis, peningkatan kepekaan ekologis terhadap dampak perubahan iklim dan pelaksanaan program-program yang ditujukan untuk mencapai pertumbuhan rendah karbon. SPREP memiliki pengalaman panjang dalam mengawasi usaha regional atau multi-negara, termasuk proyek-proyek yang dibiayai 


\section{Jurnal Asia Pacific Studies \\ Volume 4 Number 2 / July - December 2020

oleh Global Environment Facility (GEF) dan disponsori oleh United Nations Development Programme (UNDP). Sebagai badan pelaksana, GEF memiliki beberapa tahun pengalaman kumulatif pada banyak program lingkungan regional yang besar, khususnya tentang perubahan iklim. Dengan aktifnya peran SPREP di Pasifik Selatan, hal tersebut akan membantu negara-negara anggotanya untuk bersama-sama menyelesaikan isu mengenai climate change.

\section{Kerangka Pemikiran}

Teori Liberal atau liberalisme dalam hubungan internasional erat kaitannya dengan gagasan berikut: (1) negara Liberal modern yang mendukung kegiatan manusia untuk pembangunan masyarakat; (2) para aktor negara dan non-negara sebagai mitra dalam proses pembangunan; (3) negara yang penuh damai berdasarkan prinsip demokrasi sebagai pendukung terbaik tatanan internasional yang penuh damai; (4) sistem ekonomi bebas di dalam negara bagian dan pada tingkat intermational; (5) perintah nasional dan internasional yang saling bergantung. Liberalisme adalah produk sejarah dan jalur pembangunan dalam tatanan internasional. Kaum liberal masa awal seperti Norman Angell dan Woodrow Wilson, yang telah menyaksikan tragedi perang dunia pertama, lebih memperhatikan ketertiban internasional yang penuh damai yang didasarkan pada kerja sama antar negara. Tatanan dunia yang penuh damai ini hanya bisa diatur oleh negara-negara bangsa liberal yang suka damai yang menghargai kebebasan dan kebebasan individu, dan mempromosikan ekonomi yang kompetitif.

Periode liberalisme awal dalam hubungan internasional yang dimulai setelah perang dunia pertama, juga dikenal sebagai utopian atau idealis liberalisme karena para protagonis percaya dalam tatanan dunia yang ideal bebas dari konflik dan perang. Namun, dengan munculnya Nazi Jerman, fasis Italia, dan gagalnya Liga Bangsa-Bangsa, paham idealis liberalisme kehilangan dasar untuk teori neo-realis, yang mulai muncul dari akhir tahun 1930an. Meskipun begitu, liberalisme dalam hubungan internasional dihidupkan kembali dengan semangat yang diperbarui setelah perang dunia kedua, karena hal itu menghasilkan gagasangagasan dan pemikiran yang lebih baru yang memperkaya pelajaran tentang disiplin. Liberalisme pasca Perang Dunia II dalam Hubungan Internasional berkembang menjadi doktrin multi-faset. Penulis seperti Robert Jackson dan Georg Sorensen telah mengidentifikasi empat cabang utama liberalisme dunia pasca-secon: liberalisme sosiologis, liberalisme saling ketergantungan, liberalisme kelembagaan dan liberalisme republik. Gagasan inti liberalisme sosial mengacu pada hubungan internasional sebagai studi hubungan antara individu, kelompok dan masyarakat, di samping studi interaksi antara pemerintah nasional. A. J. P. Taylor, John Burton, dan James Rosenau adalah ahli teori terkemuka dari liberalisme sosiologis yang memandang hubungan internasional sebagai studi hubungan 'informal' di antara kelompok dan masyarakat di luar hubungan formal antara pemerintah negara yang berbeda.

Liberalisme saling ketergantungan percaya bahwa dengan kemajuan ilmu pengetahuan, teknologi dan perdagangan, negara-negara bangsa terlibat dalam suatu jaringan ketergantungan antar sesama yang rumit. Teoretisi Liberal seperti David Haas, Ernst Haas, Robert Keohane dan Joseph Nye berpendapat bahwa negara-negara bagian modern adalah organisasi kesejahteraan dan bukan organisasi keamanan. Tujuan utama negara-negara kesejahteraan ini adalah untuk memastikan ketertiban koperasi international yang didasarkan pada pemahaman bersama. Para aktor non-negara adalah instrumen penting dari ordo kerja sama internasional ini yang berupaya mempromosikan perdamaian, dan bukan konflik, dalam liberalisme institusional dunia (international) seperti WTO (World Trade Organization), 
NATO (North Atlantic Treaty Organization) dan UE (Uni Eropa) membantu menggalakkan kerjasama antarnegara di dunia dan memperkuat upaya untuk perdamaian international. Lembaga liberal seperti Volker Rittberger, O. R. Young, dan Robert Keohane berpandangan bahwa lembaga-lembaga internasional membantu mengurangi kemungkinan terjadinya anarki di dunia dengan memajukan kerjasama berdasarkan kepentingan bersama. Dengan demikian, misalnya, lembaga internasional seperti WTO mendukung kepentingan ekonomi negaranegara bagian dan membantu mencapai kerja sama antar negara di dunia, yang berarti kerjasama internasional ini memperkuat perdamaian internasional.

SPREP adalah organisasi regional yang didirikan oleh Pemerintah dan Administrasi Pasifik yang bertugas untuk melindungi dan mengelola lingkungan serta sumber daya alam Pasifik. Kantor pusatnya berbasis di Apia, Samoa dengan sekitar 100 staf. Ada juga kantor SPREP di Fiji dengan empat staf serta petugas SPREP yang ditempatkan di Negara Federasi Mikronesia, Republik Kepulauan Marshall, Kepulauan Solomon, dan Vanuatu. SPREP memiliki anggaran tahunan sebesar USD \$ 29 juta pada tahun 2018. Pembentukan SPREP mengirimkan sinyal yang jelas kepada komunitas global akan komitmen mendalam dari Pemerintah dan Administrasi Kepulauan Pasifik untuk pengelolaan lingkungan yang lebih baik dalam konteks pembangunan berkelanjutan. Arahan strategis SPREP tertuang jelas dalam Renstra SPREP 2017-2026. Rencana tersebut menguraikan mandat, visi dan program untuk organisasi, dan memberikan penekanan kuat pada penyampaian layanan yang efektif ke negara dan wilayah Anggota SPREP.

SPREP dipandu oleh visinya untuk masa depan, yaitu lingkungan Pasifik yang tangguh, mempertahankan mata pencaharian dan warisan alam selaras dengan budaya kita. Mandat SPREP adalah untuk mempromosikan kerjasama di kawasan Pasifik dan memberikan bantuan untuk melindungi dan meningkatkan lingkungan dan untuk memastikan pembangunan berkelanjutan untuk generasi sekarang dan masa depan. SPREP memiliki 21 negara dan wilayah anggota kepulauan Pasifik (Samoa Amerika, Kepulauan Cook, Negara Federasi Mikronesia, Fiji, Polinesia Prancis, Guam, Kiribati, Kepulauan Marshall, Nauru, Kaledonia Baru, Niue, Northern Marianas, Palau, Papua Nugini, Samoa, Kepulauan Solomon, Tokelau, Tonga, Tuvalu, Vanuatu dan Wallis \& Futuna) dan 5 negara maju (Australia, Prancis, Selandia Baru, Inggris dan Amerika Serikat) dengan kepentingan langsung di kawasan. Dengan adanya kepentingan bersama dari 21 ngera ini dapat dilihat bahwa adanya rasa saling membutuhkan sehingga diperlukan adanya kerjasama.

Liberalisme saling ketergantungan percaya bahwa dengan kemajuan ilmu pengetahuan, teknologi dan perdagangan, negara-negara bangsa terlibat dalam suatu jaringan ketergantungan antarsesama yang rumit. Teoretisi Liberal seperti David Haas any, Ernst Haas, Robert Keohane dan Joseph Nye berpendapat bahwa negara-negara bagian modern adalah organisasi kesejahteraan dan bukan organisasi keamanan. Tujuan utama negara-negara kesejahteraan ini adalah untuk memastikan ketertiban koperasi internasional yang didasarkan pada pemahaman bersama. Untuk mewujudkan tujuan dari kerjasama tentu saja diperlukan komitmen, sehingga adanya suatu pemahaman saling membutuhkan antar negara akan menimbulkan manfaat positif di kawasan Pasifik. Pendekatan liberalisme juga beranggapan bahwa adanya rasa saling benci atau beban yang menimbulkan konflik akan sangat sulit tercipta, jika semua negara sudah saling bergantung satu sama lainnya. 


\section{Pembahasan}

\section{A. Program Pacific Ecosystem-Based Adaptation to Climate Change (PEBACC)}

Perubahan iklim menjadi masalah serius, yang saat ini menjadi perhatian penting negara - negara di dunia internasional. Begitu juga dengan regional Asia Pasifik, perubahan iklim merupakan ancaman yang mendapat perhatian lebih dari negara - negara wilayah Kepulauan Pasifik. Adanya masalah perubahan iklim ini, regional Asia Pasifik tidak hanya tinggal diam, dengan begitu dibentuklah badan antar pemerintah yang dinamakan The Secretariat of the Pacific Regional Environment (SPREP) untuk menangani permasalahan tersebut. Perubahan iklim merupakan ancaman serius yang dapat mengganggu pembangunan berkelanjutan di wilayah Pasifik, dan perubahan iklim juga dapat mengakibatkan berbagai macam situasi, seperti contoh, naiknya permukaan laut, berubahnya pola cuaca, pemanasan laut dan berdampak pada pengasaman laut. Semua hal tersebut, tentunya akan sangat berdampak pada sektor ekonomi dari negara - negara di wilayah Kepulauan Pasifik.

Oleh karena itu hal ini menjadi sangat penting dikarenakan wilayah Kepulauan Pasifik ini harus mampu berinvestasi dalam pilihan untuk mengatasi faktor iklim dan juga non-iklim secara bersamaan. Dengan adanya tuntutan seperti ini, SPREP menunjukkan perannya, sebagai badan yang berguna untuk memberi bantuan dan layanan terhadap negara - negara Kepulauan Pasifik, dalam konservasi dan pengelolaan lingkungan. SPREP menunjukkan peran pentingnya, dengan proyek yang dinamakan Pacific Ecosystem - Based Adaptation to Climate Change (PEBACC). Proyek ini merupakan kerjasama dari Pemerintah Jerman dengan negara - negara di wilayah Kepulauan Pasifik, melalui SPREP. Dalam proyek ini, Pemerintah Jerman berperan sebagai penyedia dana untuk berjalannya program kerjasama ini. Sedangkan peran SPREP dalam program kerja ini adalah sebagai pihak pelaksana program, agar program - program di dalamnya dapat berjalan dengan baik dan tepat sesuai target.

PEBACC ini merupakan proyek lima tahun. Proyek ini berjalan dari periode tahun 2014 sampai tahun 2019, dan memiliki dana sebesar $€ 4,95$ juta untuk mendukung berhasilnya program kerja ini. PEBACC merupakan program kerja dari SPREP yang berguna untuk mengeksplorasi dan mempromosikan untuk setiap negara di wilayah Kepulauan Pasifik dapat beradaptasi dengan perubahan iklim yang terjadi. Tujuan utama dari program PEBACC ini adalah program Ecosystem-based Adaptation (EbA). EbA atau dapat disebut juga dengan adaptasi berbasis ekosistem ini adalah penggunaan keanekaragaman hayati dan ekosistem, sebagai bagian dari strategi adaptasi keseluruhan, untuk membantu orang beradaptasi dengan dampak buruk dari perubahan iklim. Hal ini bertujuan untuk menjaga serta meningkatkan ketahanan dan mengurangi kerentanan ekosistem dalam menghadapi dampak dari perubahan iklim itu sendiri.

Program EbA dari PEBACC dapat membantu berjalannya adaptasi dengan cara melindungi ekosistem yang utuh, mengelola sumber daya alam dan juga memulihkan ekosistem yang terdegradasi. Dapat diambil contoh yaitu dengan menjaga hutan tetap utuh atau menanam kembali, kemudian juga menjaga laut agar tetap memiliki air yang sehat serta menjaga kelestarian terumbu karang yang dapat mendukung populasi ikan yang lebih besar. PEBACC mengharapkan EbA ini dapat diintegrasikan ke dalam pengembangan, perubahan iklim terhadap tanggapan adaptasi, dan kebijakan manajemen sumber daya alam serta proses perencanaan tiga negara kepulauan Pasifik yang menyediakan model yang dapat ditiru oleh negara lain dalam kawasan Pasifik. Dalam program kerjasama ini, negara yang berpartisipasi dalam berjalannya PEBACC ini bukan hanya antara Jerman dengan SPREP. Ada tiga negara kepulauan Pasifik yang juga terlibat dalam berjalannya PEBACC yaitu Fiji, Solomon, dan juga Vanuatu. Ketiga negara ini juga diharapkan menjadi negara model bagi negara - negara lain di kawasan kepulauan Pasifik ini. 
Dalam pelaksanaan program kerjanya, PEBACC memiliki empat output, yaitu :

1. Analisis dan pemetaan ketahanan ekosistem dan sosial - ekonomi sebagai dasar perencanaan adaptasi di tingkat nasional, provinsi dan masyarakat.

2. Opsi EbA dianalisis, diprioritaskan, dan rencananya dikembangkan.

3. Rencana EbA dilaksanakan dengan manfaat yang ditunjukkan.

4. Komunikasi dan produk penjangkauan dikembangkan untuk mempromosikan integrasi opsi EbA ke dalam kebijakan perubahan iklim, rencana dan proyek.

\section{B. Pacific Island Forum (PIF)}

Pacific Island Forum (PIF) merupakan forum kerja sama antar negara - negara di kawasan Pasifik yang meliputi 18 negara/wilayah, yaitu Australia, Kepulauan Cook, Fiji, Polinesia Perancis, Kaledonia Baru, Kiribati, Kepulauan Marshall, Nauru, Niue, Federasi Mikronesia, Palau, Papua Nugini, Selandia Baru, Kepulauan Solomon, Tuvalu, Tonga, Samoa dan Vanuatu. Forum ini didirikan pada tahun 1971, dan bertujuan memperkuat kerjasama dan integrasi kebijakan negara-negara Pasifik dalam mencapai pertumbuhan ekonomi, pembangunan berkelanjutan, tata kelola pemerintahan yang baik, serta keamanan regional bersama. Perubahan iklim merupakan isu global karena tidak hanya sebagian wilayah saja yang terdampak, tetapi seluruh belahan dunia. Kondisi geografis dan ketergantungan masyarakat dari negara-negara di wilayah Kepulauan Pasifik terhadap Sumber Daya Alam (SDA) yang menjadi sumber utama mata pencaharian mereka, dianggap sebagai wilayah yang paling rentan terhadap dampak kerugian yang disebabkan oleh perubahan iklim. Maka dari itu, jika tidak adanya kesadaran dan collective action dari berbagai pihak internasional, dampak buruk dari perubahan iklim yang masif tidak hanya dirasakan di wilayah Kepulauan Pasifik saja, tetapi akan merata ke berbagai negara.

Besarnya akumulasi produksi karbon dioksida yang berbahaya bagi lapisan atmosfer bumi dan mengancam kelangsungan makhluk hidup, menjadi tanggung jawab bersamakhususnya negara-negara maju yang berperan besar dalam penghasil emisi karbon dioksida yang besar dari kegiatan industri yang masif. Perihal ini, Cina dan Amerika Serikat menjadi negara terbesar penghasil emisi karbon dioksida terbanyak dengan total emisi yang dihasilkan, yaitu 10.06GT dan 5.41GT (Union of Concerned Scientists, 2018). Di lain sisi, negara-negara berkembang memiliki kendalanya sendiri terkait isu ini, seperti memiliki kapastias yang lebih kecil untuk beradaptasi dan menangani kendala yang ditimbulkan dari dampak kerugian perubahan iklim yang dirasakan. Sehingga, sinergitas antara negara maju dan negara berkembang - seperti negara-negara di Kepulauan Pasifik-diperlukan untuk bantuan dan pengupayaan mitigasi dampak yang diberikan. Dampak kerugian perubahan iklim dengan kondisi geografis yang dimiliki dari negara-negara di wilayah Kepulauan Pasifik menjadikan negara-negara ini lebih rentan terhadap bencana alam. Seperti halnya, siklon tropis, gelombang air laut yang naik ke wilayah daratan, serta banjir dengan intensitas dan frekuensinya yang terus meningkat. Hal ini diperkirakan akan menyebabkan beberapa pulau yang akan tenggelam.

KTT PIF ke-50 membahas isu-isu yang menjadi perhatian bersama di Pasifik, antara lain keamanan regional, perubahan iklim, dan keamanan maritim. Kainaki II Declaration for Urgent Climate Change Action adalah hasil dari KTT PIF ini dan disepakati juga penyusunan 2050 Strategy for the Blue Pacific Continent. Pembahasan isu perubahan iklim menjadi topik bahasan mayoritas pada KTT PIF ini. Fokus utama dari negara-negara PIF ialah menyusun posisi bersama untuk diperjuangkan pada pertemuan COP25 mendatang. PIF mempunyai tujuan untuk menciptakan perdamaian, harmoni, kesejahteraan sosial dan kemakmuran bagi masyarakat Pasifik. Sehingga perubahan iklim menjadi suatu yang mengancam tujuan tersebut dan harus ditanggapi secara cepat dan tepat. Pacific Islands Forum Leaders 


\section{Jurnal Asia Pacific Studies \\ Volume 4 Number 2 / July - December 2020

Declaration on Climate Change adalah salah satu bentuk keseriusan dan kepedulian PIF terhadap isu ini. Upaya selanjutnya yang dilakukan oleh PIF dalam menghadapi perubahan iklim adalah pembuatan Framework for The Resilient Development of The Pacific (FRDP). Kerangka tersebut akan dijadikan panduan bagi semua lapisan masyarakat di wilayah Kepulauan Pasifik untuk meningkatkan ketahanan terhadap bencana yang disebabkan oleh perubahan iklim.

Dalam menghadapi isu perubahan iklim ini, PIF menjalin kerjasama dengan Jepang dan juga Uni Eropa, yang keikutsertaannya berperan untuk membantu memberdayakan masyarakat, memberikan pelatihan dan juga tentunya bantuan suntikan dana. Bahkan salah satu bantuan yang diberikan oleh Jepang adalah melalui Pacific Leader Meeting 8 (PALM8), yang berupa terbentuknya Pacific Climate Change Center (PCCC), yang berpusat di Samoa. Pembentukan PCCC ini diharapkan dapat membantu negara di wilayah kepulauan Pasifik ini untuk dapat melakukan penelitian seputar perubahan iklim, yang dimana hasil dari penelitian tersebut dapat digunakan sebagai panduan atau pedoman bagi negara - negara dalam menentukan serta merumuskan tindakan dan kebijakan yang tepat guna menghadapi perubahan iklim di wilayah Kepulauan Pasifik. Pacific Climate Change Center (PCCC) memiliki beberapa tujuan, yaitu:

1. Memberikan program pengembangan kapasitas dalam adaptasi, mitigasi, layanan iklim, dan pengembangan proyek. Ini akan mempromosikan dan menumbuhkan penelitian terapan, mendorong inovasi dan membangun kapasitas di bidang-bidang ini.

2. Meningkatkan arus informasi praktis antara layanan yang terpenuhi, praktisi iklim, pembuat kebijakan, peneliti, ilmuwan dan mereka yang menerapkan kebijakan, program, dan proyek.

3. Memberikan ruang bagi peneliti dan ahli yang berkunjung untuk bekerja dari PCCC dan bekerja langsung dalam memberikan dukungan kepada dan untuk kepentingan negara serta wilayah pulau Pasifik.

4. Satukan mitra untuk menemukan solusi inovatif untuk tantangan yang disebabkan oleh perubahan iklim.

PCCC menumbuhkan inovasi dan mempromosikan pengembangan layanan iklim serta produk baru, dan PCCC juga membantu untuk menyatukan para peneliti, dengan pembuat kebijakan serta praktisi. Hal ini diharapkan agar ditemukannya solusi atas tantangan utama terkait iklim, dan solusi yang ditemukan merupakan solusi yang terbaik untuk semua pihak dalam menghadapi perubahan iklim. PCCC juga mendukung implementasi dari Roadmap Pasifik untuk Penguatan Layanan Iklim. Adanya partisipasi aktif dalam proses negosiasi di PIF memberikan kepedulian antar negara dengan membantu secara finansial dan teknis.

\section{Kesimpulan}

Pemanasan global yang terjadi di dunia selama abad terakhir ini, telah menyebabkan terjadinya perubahan iklim atau biasa dikenal dengan climate change. Perubahan iklim merupakan suatu ancaman yang dapat mengganggu pembangunan berkelanjutan di wilayah Kepulauan Pasifik, terlebih lagi adanya isu kenaikan air laut yang dapat menenggelamkan pulau-pulau didalamnya. Dengan adanya permasalahan perubahan iklim ini, dibentuklah badan antar pemerintah yang dinamakan dengan The Secretariat of the Pacific Regional Environment (SPREP) yang bertujuan untuk menangani permasalahan mengenai perubahan iklim di Kepulauan Pasifik. SPREP mempromosikan integrasi adaptasi perubahan iklim dan manajemen risiko bencana melalui peningkatan kapasitas dan pendekatan berbasis ekosistem. 
SPREP merupakan saluran utama untuk mengefektifkan penggunaan dari United Nations Framework Convention on Climate Change (UNFCCC) dan Conference of the Parties processes, the Paris Agreement, serta inisiatif iklim global lainnya. Di tingkat regional, SPREP mempromosikan Framework on Resilient Development in the Pacific: Pendekatan Terpadu untuk Perubahan Iklim dan Manajemen Risiko Bencana (FRDP) untuk memandu pendekatan kolaboratif dengan organisasi regional, pendonor, dan PBB untuk memperkuat ketahanan terhadap perubahan iklim. Meningkatkan akses pendanaan perubahan iklim adalah prioritas tinggi bagi Anggota Kepulauan Pasifik, dan SPREP akan mendukung anggotanya melalui perannya sebagai entitas terakreditasi untuk Dana Adaptasi dan Dana Iklim Hijau dan melalui sumber lain. Sebagai Badan Pelaksana Regional untuk Dana Adaptasi, Dana Iklim Hijau, dan melalui mekanisme pembiayaan lainnya, SPREP mampu memaksimalkan akses dan memanfaatkan pendanaan iklim bagi Anggota.

Terkait dengan perubahan iklim, SPREP menunjukkan perannya sebagai badan yang berguna untuk memberi bantuan dan layanan terhadap negara - negara di Kepulauan Pasifik, dalam konservasi dan pengelolaan lingkungan. SPREP juga menunjukkan peran pentingnya, dengan proyek yang dinamakan Pacific Ecosystem - Based Adaptation to Climate Change (PEBACC). Proyek ini merupakan kerjasama dari Pemerintah Jerman dengan negara - negara di wilayah Kepulauan Pasifik. Dalam proyek ini, Pemerintah Jerman berperan sebagai pendonor untuk berjalannya program kerjasama. Sedangkan peran SPREP dalam program kerjasama ini adalah sebagai pihak pelaksana program, supaya program - program di dalamnya dapat berjalan dengan baik dan tepat sesuai target.

Selain adanya peran dari badan antar pemerintah SPREP dalam penanganan perubahan iklim di Kepulauan Pasifik ini, adapula peran dari Pasific Island Forum (PIF) terkait perubahan iklim yang diinisiasikan lewat Pacific Islands Forum Leaders Declaration on Climate Change. Berbagai upaya yang dilakukan oleh PIF dalam menghadapi perubahan iklim ini, dimulai dengan pembuatan framework for the resilient develompment of the Pacific. Kerangka tersebut akan dijadikan panduan bagi semua lapisan masyarakat di wilayah Kepulauan Pasifik untuk meningkatkan ketahanan terhadap bencana yang disebabkan oleh perubahan iklim itu sendiri. Dalam menghadapi isu perubahan iklim ini, PIF menjalin kerjasama dengan Jepang dan juga Uni Eropa, yang keikutsertaannya berperan untuk membantu memberdayakan masyarakat, memberikan pelatihan dan juga tentunya memberikan bantuan dana.

Salah satu bantuan yang diberikan oleh Jepang adalah melalui Pacific Leader Meeting 8 (PALM8), yang berupa terbentuknya Pacific Climate Change Center (PCCC). Pembentukan PCCC ini diharapkan dapat membantu negara di wilayah Kepulauan Pasifik untuk dapat melakukan penelitian seputar perubahan iklim. Hasil dari penelitian tersebut dapat digunakan sebagai panduan atau pedoman bagi negara - negara dalam menentukan serta merumuskan tindakan dan kebijakan yang tepat guna menghadapi perubahan iklim di wilayah kepulauan Pasifik. PCCC juga berguna untuk menumbuhkan inovasi dan mempromosikan pengembangan layanan iklim serta produk baru, kemudian PCCC juga membantu untuk menyatukan para peneliti dengan pembuat kebijakan serta praktisi. 


\section{DAFTAR PUSTAKA}

\section{Buku}

Carter, George. 2015. Establishing a Pacific Voice in the Climate Change Negotiations. In Fry G. \& Tarte S. (Eds.), The New Pacific Diplomacy (pp. 205-220). ANU Press. Retrieved Desember 20, 2020, from http://www.jstor.org/stable/j.ctt19w71mc.23

Catterjerjee, A. 2010. International Relations Today (Concepts And Aplications). Delhi: Dorling Kinderlsley.

Connell, John. 2015. Vulnerable Islands: Climate Change, Tectonic Change, and Changing.

Conor Houghton, G. D. 2001. Climate change 2001: the scientific basis. Cambridge: Cambridge University Press.

Livelihoods in the Western Pacific. 2015. Contemporary Pacific; Honolulu Vol. 27 Iss 1:1-37

Campbell, John. 2000. Adapting to climate change : incorporating climate change adaptation into development activities in Pacific island countries. Apia, Samoa : SPREP.

Williams, A. 2006. Liberalism and War. New York: Routledge.

\section{Situs}

Kementrian Luar Negeri Republik Indonesia. 2019. Pacific Island Forum (PIF) https://kemlu.go.id/portal/i/read/132/halaman_list_lainnya/pacific-island-forum-pif Diakses 22 Desember 2020.

SPREP. 2012. pacificclimatechange.org. Diakses 15 Desember 2020, www.pacificclimatechange.net/index.php/eresources/documents?task=view\&id=194\& catid $=0$

SPREP. 2015. International Climate Change Adaptation and Initiative, Pacific Climate Change Science Program. Diakses 18 December 2020, https://www.pacificclimatechangescience.org/wpcontent/uploads/2013/06/15_PCCSP _Vanuatu_8pp.pdf

SPREP. 2015. International Climate Initiative . Diakses 18 Desember 2020, from https://www.internationalclimateinitiative.com/fileadmin/Dokumente/2015/PEBACC _Factsheet.pdf

SPREP. 2016. Pacific Ecosystems - based Adaptation to Climate Change Webpage. Diakses 18 Desember 2020, from https://www.pacificclimatechange.net/link/pebacc-webpage

SPREP. 2018. Pacific Ecosystems - based Adaptation to Climate Change. Diakses 19 Desember 2020 , https://www.sprep.org/attachments/bem/PEBACC/PEBACC_Factsheet_Regional.com pressed.pdf

SPREP. 2020. About Us SPREP. Diakses dari sprep.org: https://www.sprep.org/about-us

SPREP.2020. Climate Change Resilience. Diakses 23 Desember 2020. https://www.sprep.org/programme/climate-change-

resilience\#: :text=SPREP\%20promotes\%20integration\%20of\%20climate, within $\% 20 \mathrm{a}$ $\mathrm{n} \% 20$ ecosystem $\% 20$ based $\% 20$ approach.\&text $=$ The $\% 20$ PCCC $\% 20$ will $\% 20$ enable $\% 2$ OSPREP,its\%20meteorological\%20support\%20to\%20Members. 
Union of Concerned Scientists. (2018). Each Country's Share of CO2 Emissions. Diakses 15 Desember 2020, ucsusa.org: https://www.ucsusa.org/resources/each-countrys-shareco2-emissions

https://www.forumsec.org/secretariat-pacific-regional-environment-programme-sprep/ 